\title{
AWARENESS AND THE ATTITUDES TOWARDS SOLID WASTE MANAGEMENT: A CASE STUDY IN TRINCOMALEE TOWN
}

\author{
Suthajini Thiruketheeswaranathan \\ Department of Agriculture Engineering, Faulty of Agriculture, \\ University of Ruhuna, Sri Lanka
}

\begin{abstract}
Sustainable development of the environment can be achieved through the proper management of solid waste. In Sri Lanka, solid waste disposal is one of the major threats nowadays. However, the practices of basic concepts on waste disposal are often neglected or paid least attention. The negative attitude towards the solid waste in developing country gives rise to chaotic situation. In Trincomalee, Municipalities are responsible for waste disposal. This study was done to assess the awareness level and the attitudes towards the solid waste among the residents of Trincomalee town, Eastern province Sri Lanka. The study was descriptive cross sectional survey in which 250 people were selected randomly and data was gathered using by questionnaire. The obtained data was tabulated and expressed into percentages for analysis. In this study, more than half of the people were aware of solid waste strategies and practices. Awareness of the E-waste disposal was very poor. So government should focus the ways to improve the people's attitudes and awareness level on solid waste management.
\end{abstract}

Key words - Solid waste, environment, sustainable development, awareness, attitudes

\section{INTRODUCTION}

The environment is the basic need for every living being. It provides the support and resources for life. Over extraction of natural resources causes the environmental degradation. Likewise improper waste disposal causes severe environmental problems (Vivek, R. 2013). It is the reason for the pollution and the infectious diseases.

Waste generated from the industries, commercial sector, institutions and municipal services are included in municipal solid waste (Singh et al., 2011). The process of collection, transportation, disposal and monitor are called as the waste management. Commonly open dumping, burning, landfill, recycling, reusing, and compost making are followed as the disposal methods (Hilburn, A. M. 2015).
In Trincomalee town area waste is collected mainly from domestic, commercial, institutional activities and municipal services. Trincomalee Municipal council is the responsible authority for waste disposal. It face challenges to maintain Effective and efficient management system for waste. Wastages are collected from the household, institutes or any other places and transported to kanniya open dumping area by unclosed tractor or other vehicle. Before the collection, separation process is very important practice for the proper waste management plan. Public are the responsible for this sorting process.so solid waste management practices depend on the level of public awareness, household income, educational level and gender (Banga M. 2013).

This study was assessed the awareness level and the attitude of public who live in Trincomalee town which is one of the developing town in eastern province, Sri Lanka.

\section{MATERIALS AND METHODS}

Study was conducted in Trincomalee town, Eastern province Sri Lanka in May 2019. It has a population about 97234. Descriptive cross section survey was done. The sample size of 250 was calculated using 95\% confidence limits. Questionnaires and the interview were used to gather data from public.

Participants were selected randomly from the household and other institutes, commercial sectors. If a house was locked during the visit the surveyors visited the adjacent house for the data collection. Data was analyzed using Minitab statistical software. Tables, frequencies and percentages were generated where necessary.

\section{RESULTS AND DISCUSSION}

Hundred and seventy (68\%) of people knew the importance of the solid waste management and the bad effect on the environment due to the improper management. however, they put the all type of garbage in the same bin and they avoid the sorting process due to the laziness. And they strongly believed that sorting is useless unless proper collection methods. Because 


\section{International Journal of Engineering Applied Sciences and Technology, 2019 \\ Vol. 4, Issue 3, ISSN No. 2455-2143, Pages 461-463 \\ Published Online July 2019 in IJEAST (http://www.ijeast.com)}

Trincomalee Municipal Council collect the waste altogether.

Only seventy two people (28.8\%) aware of E-waste and forty five people (18\%) out of 250 participants knew the disposal method of E-waste. Ninety people (36\%) among the participants try to reuse the waste. There were few awareness program conducted by Trincomalee Municipal Council and the participation of those meeting/awareness program was law about $53 \%$.

Table 1: Awareness of waste management

\begin{tabular}{|c|c|c|}
\hline & Yes & No \\
\hline $\begin{array}{l}\text { Did you ever attend any awareness } \\
\text { program conducted by } \\
\text { authorities } \\
\text { management? }\end{array}$ & $53 \%$ & $47 \%$ \\
\hline $\begin{array}{l}\text { Do you know about segregation of } \\
\text { waste? }\end{array}$ & $68 \%$ & $32 \%$ \\
\hline $\begin{array}{l}\text { Do you know the complications of } \\
\text { improper waste management }\end{array}$ & $46 \%$ & $54 \%$ \\
\hline Are you aware of e-waste? & $28.8 \%$ & $71.2 \%$ \\
\hline $\begin{array}{l}\text { Do you know how to dispose the e- } \\
\text { waste? }\end{array}$ & $18 \%$ & $82 \%$ \\
\hline $\begin{array}{l}\text { Do you know the effective mechanism } \\
\text { for house hold waste management? }\end{array}$ & $64 \%$ & $36 \%$ \\
\hline $\begin{array}{l}\text { Do you think solid waste management } \\
\text { in the city is the sole responsibility of } \\
\text { the local authorities? }\end{array}$ & $41.6 \%$ & $58.4 \%$ \\
\hline
\end{tabular}

Table 2: Awareness level of public associated with Education level

\begin{tabular}{|l|c|c|c|}
\hline Education level & Aware & Not aware & Total \\
\hline Uneducated & $6(30 \%)$ & $14(70 \%)$ & 20 \\
\hline Primary & $46(62 \%)$ & $28(38 \%)$ & 118 \\
\hline Up to ordinary level & $86(73 \%)$ & $22(27 \%)$ & 38 \\
\hline University level & $32(84 \%)$ & $6(16 \%)$ & \\
\hline
\end{tabular}

Only $36.8 \%$ of people (92) followed the waste reduction process. Any participants didn't maintain biogas production from the kitchen waste. Only 3 people $(1.2 \%)$ out of 250 participants, associated with compost making. Most of the participants stated that lack of the land availability is the reason for not to produce compost. 


\section{International Journal of Engineering Applied Sciences and Technology, 2019 \\ Vol. 4, Issue 3, ISSN No. 2455-2143, Pages 461-463 \\ Published Online July 2019 in IJEAST (http://www.ijeast.com)}

Table 3: Waste storage methods and disposal practices

\begin{tabular}{|l|c|}
\hline Bags for storage & Yes \\
\hline Container for storage & $92 \%$ \\
\hline Every day waste collection & $0 \%$ \\
\hline $\begin{array}{l}\text { Twice a week waste } \\
\text { collection for }\end{array}$ & $82 \%$ \\
\hline $\begin{array}{l}\text { Closed trucks for } \\
\text { transportation }\end{array}$ & $29 \%$ \\
\hline $\begin{array}{l}\text { Open trucks } \\
\text { transportation }\end{array}$ \\
\hline
\end{tabular}

\section{CONCLUSION}

Most of the people have knowledge and aware on waste management. But practically they avoid to follow the sustainable practices for proper solid waste management. Awareness of the E-waste disposal was very poor. So government should focus the ways to improve the people's attitudes and awareness level on solid waste management.

\section{REFERENCES}

1. Addaney, M., \& Anarfiwaah, O. R. (2015). Critical Issues of Municipal Solid Waste Management in Ghana. JENRM, 2 (1), 30-36.

2. Adejobi, O., \& Olorunnimbe, R. O. (2012). Challenges of Waste Management and Climate Change in Nigeria: Lagos State Metropolis Experience. African J. Sci. Res., 7 (1), 346-362.

3. Asuamah, S., Kumi, E., \& Kwarteng, E. (2012). Attitude toward Recycling and Waste Management. Science Education Development Institute, 2, 158-167.

4. Ayodeji, I. (2012). Waste Management Awareness, Knowledge and Practices of Secondary Schoolteachers in Ogun State, Nigeria. The Journal of Solid Waste Technology and Management, 37, 221-234.

5. Banga, M. (2013). ) Household Knowledge Attitudes and Practices in Solid Waste Segregation and Recycling: The Case of Urban
Kampala. Zambia Social Science Journal, 2, 2739.

6. Enete, I. (2010). Potential Impacts of Climate Change on Solid Waste Management in Nigerian. Journal of Sustainable Development in Africa, 12, 101-103.

7. Hilburn, A. M. (2015). Participatory risk mapping of garbage-related issues in a rural Mexican municipality. Geographical Review, 105 (1), 41-60.

8. Singh et al. (2011). An overview for exploring the possibilities of energy generation from Municipal solid waste (MSW) in Indian scenario. Renewable and Sustainable Energy Reviews, 15 (9), 4797-4808.

9. Vivek, R., Licy, C., Saritha, K., Anies, T., \& Josphina, C. (2013). Awareness, Attitude and Practice of School Students towards Household Waste Management. Journal of Environment, 02 (6), 147-150. 